\title{
Microcystins-LR, -YR and -RR in Six Bulgarian Water Bodies of Health and Conservational Importance (2012-2014)
}

\author{
Vera Pavlova1 ${ }^{*}$, Maya Stoyneva-Gärtner², Blagoy Uzunov², Zlatka Bratanova1, \\ Antoaneta Lazarova ${ }^{1}$, Irina Karadjova ${ }^{3}$ \\ ${ }^{1}$ National Centre of Public Health and Analyses, Sofia, Bulgaria \\ 2Department of Botany, Faculty of Biology, Sofia University "St. Kliment Ohridski”, Sofia, Bulgaria \\ ${ }^{3}$ Department of Analytical Chemistry, Faculty of Chemistry and Pharmacy, Sofia University "St. Kliment \\ Ohridski", Sofia, Bulgaria \\ Email: *vera_pavlova@abv.bg
}

Received 22 September 2015; accepted 23 November 2015; published 27 November 2015

Copyright (C) 2015 by authors and Scientific Research Publishing Inc.

This work is licensed under the Creative Commons Attribution International License (CC BY). http://creativecommons.org/licenses/by/4.0/

(c) (i) Open Access

\section{Abstract}

This study presented the results of HPLC-DAD microcystin and nodularin analyses from five Bulgarian water bodies (reservoirs Stoudena, Pchelina and Bistritsa, and lakes Dourankoulak and Vaya) carried out in 2012-2014, as a continuation of our work from 2004 to 2005 and in 2011, and first data on microcystins in the lake Momin Brod were detected in the period 2012-2014. The total concentration of microcystins in water samples ranged from 0.1 to $1.8 \mu \mathrm{g} / \mathrm{l}$ and their amount in the concentrated biomasses from net samples ranged from 1.35 to $296 \mu \mathrm{g} / \mathrm{g}$ (d.w.). The presence of the most toxic microcystin-LR was recorded in all studied lakes and reservoirs, where also microcystins RR and YR were detected, but no microcystin-LA and nodularin were found.

\section{Keywords}

Cyanoprokaryotes, Cyanobacteria, Cyanotoxins

\section{Introduction}

Cyanoprokaryotes (=cyanobacteria = blue-green algae) are photosynthetic prokaryotic organisms which have inhabited the Earth for approximately 3.5 billion years [1]. Recently they continue to occur naturally in different

\footnotetext{
${ }^{*}$ Corresponding author.
}

How to cite this paper: Pavlova, V., Stoyneva-Gärtner, M., Uzunov, B., Bratanova, Z., Lazarova, A. and Karadjova, I. (2015) Microcystins-LR, -YR and -RR in Six Bulgarian Water Bodies of Health and Conservational Importance (2012-2014). Journal of Water Resource and Protection, 7, 1375-1386. http://dx.doi.org/10.4236/iwarp.2015.716111 
surface waters. Under some favourable conditions (e.g. nutrient enrichment, increased temperature, pH, water column stability, and insolation) they can rapidly reproduce and multiply cause "blooms" [2]-[5]. These blooms can be harmful to the environment, animals, and human health since some species of cyanobacteria produce toxic secondary metabolites, known as cyanotoxins ([6] [7] among the many others). The most widespread cyanotoxins are the cyclic peptide toxins called microcystins (MCs), from which at least 80 are known, including microcystin-LR (MC-LR) [8]. The last is generally considered one of the most toxic [8] and therefore World Health Organization (WHO) has recommended a provisional guideline value for MC-LR $1 \mu \mathrm{g} / \mathrm{l}$ for drinking water [9]. Until nowadays most of the developed regulations or guidelines for MCs in drinking water and recreational waters in different countries of the world are based on this value [8]. In spite of the recognition of the problem of water blooms, and real and potential presence of MCs in Bulgarian waters, the studies on the topic are scarce ([10] and citations there) and no regulatory guidelines for cyanotoxin content in drinking and recreational waters exist in the Bulgarian legislation. This study presented the results of MC analyses by HPLC DAD from five Bulgarian water bodies (reservoirs Stoudena, Pchelina and Bistritsa, and lakes Dourankoulak and Vaya) carried out in 2012-2014, as a continuation of our previous studies [10]-[13]; and first data on MCs in the lake MominBrod were detected in the period 2012-2014.

\section{Material and Methods}

\subsection{Studied Sites}

Sampling was carried out in six Bulgarian water bodies of health and conservational importance, five of which are mostly used for sports, fishing and recreation and one is a drinking water reservoir (Figure 1; Table 1). Five of the water bodies have been investigated before for MC presence [10]-[13], while the lake Momin Brod (known also as Mominbrodsko Blato) has been examined for first time. The all three studied reservoirs (Stoudena, Pchelina and Bistritsa) and the lake Momin Brod are inland, located in the Western part of the country, on the European Bird migration route Via Aristotelis. The reservoir Stoudena provides drinking water to the second (after the capital Sofia) most populated town in Western Bulgaria-Pernik. The lake Momin Brod is situated nearby the outfall of rivulet Lom in the Danube River and has been declared as protected Natura 2000 site. The Black Sea coastal lakes Dourankoulak and Vaya, located on the bird migration route Via Pontica, shelter many rare and endangered bird species and are well-known sites of global, European and national conservation importance, declared as Protected localities, Ramsar sites, Important bird areas and Natura 2000 sites. The six stu-

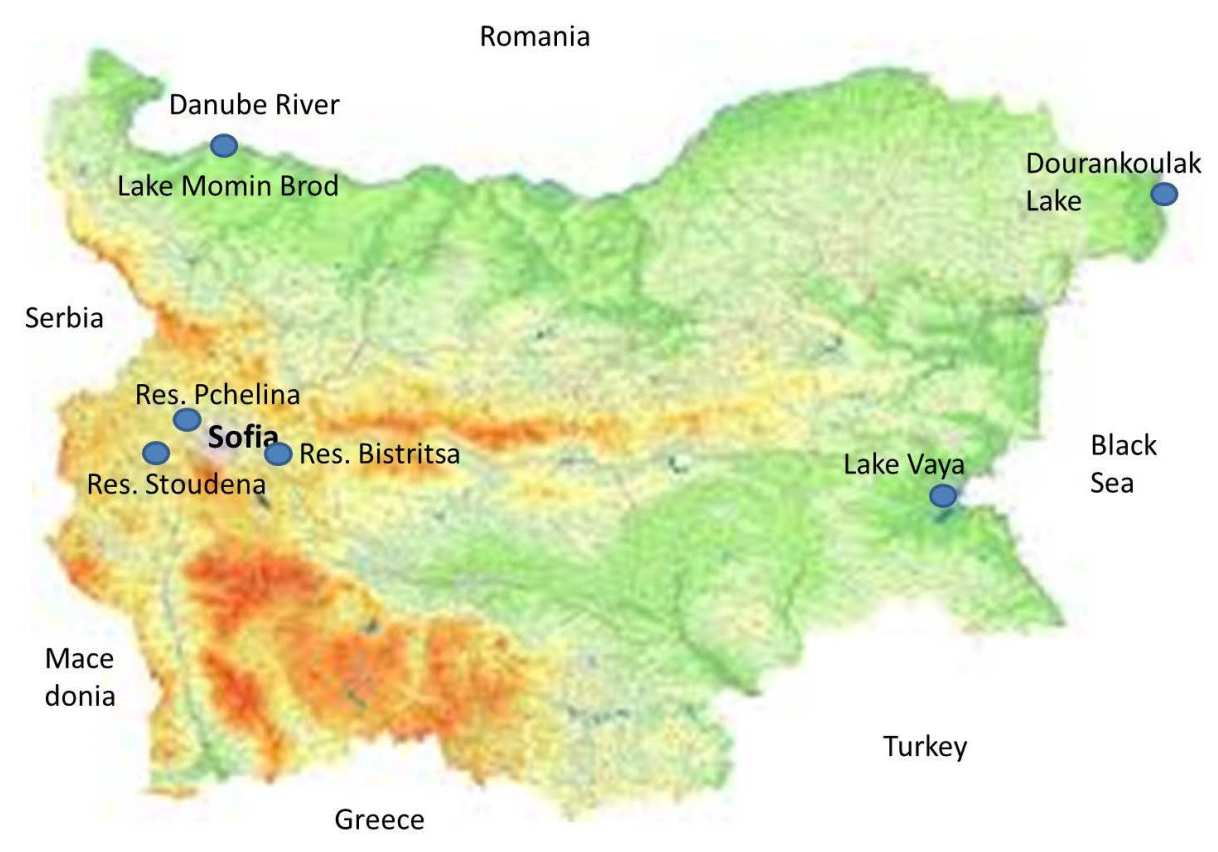

Figure 1. Map of Bulgaria with the location of studied six water bodies: Lake Momin Brod, Reservoir Stoudena, Reservoir Pchelina, Reservoir Bistritsa, Lake Dourankoulak and Lake Vaya. 
Table 1. Cyanoprokaryotic taxa, concentrations and structural variants of microcystins (intracellular + extracellular) with measured amounts of nitrogen and phosphorous in investigated Bulgarian lakes and reservoirs (WS-quantitative water sample; NS—qualitative net sample; d.w.: dry weight, n.d.: not detectable, n.a.: not analyzed, “-”: not applicable; 0—not found; in brackets are added cyanoprokaryotes with biomass $<0.0001 \mathrm{mg} / \mathrm{l})$.

\begin{tabular}{|c|c|c|c|c|c|c|c|}
\hline № & $\begin{array}{l}\text { Water source/ } \\
\text { sample type/data }\end{array}$ & $\begin{array}{c}\text { Taxa of } \\
\text { Cyanoprokaryota found }\end{array}$ & $\begin{array}{c}\text { Biomass } \\
\text { [mg/l] }\end{array}$ & $\begin{array}{c}\text { Microcystins } \\
\text { [ } \mu \mathrm{g} / \mathrm{l} \text { for WSs; } \mu \mathrm{g} / \mathrm{g} \text { d.w. } \\
\text { for "biomasses" from NSs] }\end{array}$ & $\mathrm{N}$ [mg/l] & $\mathbf{P}[\mathrm{mg} / \mathrm{l}]$ & $\mathbf{N} / \mathbf{P}$ \\
\hline \multirow[t]{4}{*}{1} & $\begin{array}{l}\text { Lake Momin } \\
\text { Brod }\end{array}$ & $\begin{array}{l}\text { Site of recreational and } \\
\text { conservational importance }\end{array}$ & & & & & \\
\hline & $\begin{array}{c}\text { WS } \\
19 / 08 / 2012\end{array}$ & $\begin{array}{c}\text { Microcystis aeruginosa } \\
\text { M. wesenbergii } \\
\text { [+Aphanocapsa cf. delicatissima; } \\
\text { Chroococcus cf. aphanocapsoides; } \\
\text { Merismopedia glauca; } \\
\text { M. tenuissima; } \\
\text { cf. Planktolyngbya sp.] }\end{array}$ & $\begin{array}{l}0.2 \\
0.6\end{array}$ & $\mathrm{LR}+\mathrm{YR} / \mathrm{LR}=1.3 / 1=1.3$ & n.a. & n.a. & n.a. \\
\hline & $\begin{array}{c}\text { NS } \\
19 / 08 / 2012\end{array}$ & n.a. & n.a. & $\begin{array}{c}\mathrm{LR}-23 \\
\mathrm{YR}-4 \\
\mathrm{LR}+\mathrm{YR} / \mathrm{LR}=27 / 23=1.17\end{array}$ & n.a. & n.a. & n.a. \\
\hline & $\begin{array}{c}\text { WS } \\
21 / 10 / 2013\end{array}$ & $\begin{array}{l}\text { Microcystis aeruginosa } \\
\text { M. wesenbergii } \\
\text { Merismopedia tenuissima } \\
\text { cf. Planktolyngbya sp. }\end{array}$ & $\begin{array}{c}3.5 \\
0.2 \\
0.001 \\
0.01\end{array}$ & $\begin{array}{c}\text { RR- } 0.4 \\
\text { YR- } 0.4 \\
\text { LR- } 1 \text { RR }+ \text { YR }+ \text { LR/LR = } \\
1.8 / 1=1.8\end{array}$ & 5.32 & 0.07 & 76 \\
\hline \multirow[t]{7}{*}{2} & $\begin{array}{l}\text { Reservoir } \\
\text { Stoudena }\end{array}$ & $\begin{array}{l}\text { Drinking water reservoir for the } \\
\text { town Pernik }\end{array}$ & & & & & \\
\hline & $\begin{array}{c}\text { WS } \\
31 / 07 / 2012\end{array}$ & [unidentified picoplankton] & $<0.001$ & n.d. & 2.31 & 0.07 & 33 \\
\hline & WS18/09/2012 & $\begin{array}{c}\text { Dolichospermum viquerii } \\
\text { [+unidentified picoplankton] }\end{array}$ & 8.8 & n.d. & 2.57 & 0.05 & 51 \\
\hline & $\begin{array}{c}\text { WS } \\
12 / 08 / 2013\end{array}$ & 0 & 0 & n.d. & 4.67 & 0.04 & 117 \\
\hline & WS14/10/2013 & $\begin{array}{l}\text { Microcystis sp. } \\
\text { [unidentified filamentous species } \\
\qquad(<1 \mu \mathrm{m}]\end{array}$ & & LR -0.1 & 6.35 & 0.05 & 127 \\
\hline & NS14/10/2013 & n.a. & n.a. & $\begin{array}{c}\mathrm{RR}-2 \\
\mathrm{YR}-0.8 \\
\mathrm{LR}-8.1 \mathrm{l} \\
\mathrm{RR}+\mathrm{YR}+\mathrm{LR} / \mathrm{LR}= \\
10.9 / 8.1=1.35\end{array}$ & - & - & - \\
\hline & WS02/10/2014 & $\begin{array}{c}\text { [Microcystis sp.; } \\
\text { unidentified filamentous species } \\
\qquad(<1 \mu \mathrm{m}]\end{array}$ & & n.d. & 6.53 & 0.03 & 218 \\
\hline \multirow[t]{7}{*}{3} & $\begin{array}{l}\text { Reservoir } \\
\text { Pchelina }\end{array}$ & $\begin{array}{l}\text { Reservoir for sport, fishing and } \\
\text { recreation }\end{array}$ & & & & & \\
\hline & WS31/07/2012 & $\begin{array}{c}\text { Microcystis sp. } \\
\text { cf. Pseudanabaena catenata } \\
\text { akinetes } \\
\text { [Woronichinia fusca] }\end{array}$ & $\begin{array}{l}0.1 \\
0.1 \\
0.1\end{array}$ & n.d. & 3.45 & 0.07 & 49 \\
\hline & NS31/07/2012 & n.a. & n.a. & trace & - & - & - \\
\hline & WS18/09/2012 & $\begin{array}{l}\text { cf. Anabaena sp. st. } \\
\text { [Planktothrix sp.; } \\
\text { unidentified picoplankton] }\end{array}$ & 10.4 & n.d. & 4.21 & 0.07 & 60 \\
\hline & NS18/09/2012 & n.a. & n.a. & trace & & & \\
\hline & WS12/08/2013 & 0 & 0 & n.d. & 4.20 & 0.09 & 47 \\
\hline & NS12/08/2013 & n.a. & n.a. & n.d. & - & - & - \\
\hline
\end{tabular}




\section{Continued}

\begin{tabular}{|c|c|c|c|c|c|c|c|}
\hline & WS14/10/2013 & $\begin{array}{c}\text { Microcystis sp. } \\
\text { [unidentified filamentous species } \\
(<1 \mu \mathrm{m} ; \\
\text { unidentified picoplankton] }\end{array}$ & 0.01 & n.d. & 5.60 & 0.10 & 56 \\
\hline & $\begin{array}{c}\text { NS } \\
14 / 10 / 2013\end{array}$ & n.a. & n.a. & n.d. & - & - & - \\
\hline & $\begin{array}{c}\text { water } \\
02 / 10 / 2014\end{array}$ & $\begin{array}{c}\text { akinetes } \\
\text { [Spirulina major] }\end{array}$ & 6.2 & $\begin{array}{c}\text { RR- } 0.07 \\
\text { YR- } 0.13 \\
\mathrm{LR}-0.17 \\
\mathrm{RR}+\mathrm{YR}+\mathrm{LR} / \mathrm{LR}= \\
0.37 / 0.17=2.18\end{array}$ & 7.47 & 0.15 & 50 \\
\hline & NS02/10/2014 & n.a. & n.a. & $\begin{array}{c}\text { RR- } 91.5 \\
\text { YR- } 71.8 \\
\text { LR- } 132.8 \\
\mathrm{RR}+\mathrm{YR}+\mathrm{LR} / \mathrm{LR}= \\
296.1 / 132.8=2.23\end{array}$ & - & - & - \\
\hline \multirow[t]{7}{*}{4} & $\begin{array}{l}\text { Reservoir } \\
\text { Bistritsa }\end{array}$ & $\begin{array}{l}\text { Reservoir for sport, fishing and } \\
\text { recreation }\end{array}$ & & & & & \\
\hline & WS31/07/2012 & 0 & 0 & n.d. & 2.75 & 0.03 & 92 \\
\hline & & $\begin{array}{c}\text { Microcystis sp. } \\
\text { [cf. }\end{array}$ & 0.2 & & & & \\
\hline & WS18/09/2012 & $\begin{array}{l}\text { Dolichospermum macrosporum; } \\
\text { unidentified filamentous species } \\
\qquad(<1 \mu \mathrm{m}]\end{array}$ & & n.d. & 2.95 & 0.03 & 98 \\
\hline & WS12/08/2013 & 0 & 0 & n.d. & 3.73 & 0.09 & 41 \\
\hline & $\begin{array}{l}\text { WS }(* \text { from rest } \\
\text { water after } \\
\text { draining of the } \\
\text { reservoir) } \\
14 / 10 / 2013\end{array}$ & Microcystis sp. & n.a. & LR- 0.6 & 3.55 & 0.06 & 59 \\
\hline & $\begin{array}{c}\text { WS } \\
02 / 10 / 2014\end{array}$ & 0 & 0 & n.d. & 4.67 & 0.04 & 117 \\
\hline \multirow[t]{5}{*}{5} & $\begin{array}{c}\text { Lake } \\
\text { Dourankoulak }\end{array}$ & $\begin{array}{l}\text { Lake for sport, fishing and } \\
\text { recreation; conservational } \\
\text { importance }\end{array}$ & & & & & \\
\hline & WS12/07/2012 & $\begin{array}{c}\text { Microcystis wesenbergii } \\
\text { [Pseudanabena mucicola; } \\
\text { Woronichinia fusca; unidentified } \\
\text { picoplankton] }\end{array}$ & 4.2 & n.d. & 4.20 & 0.32 & 13 \\
\hline & WS8/08/2012 & $\begin{array}{l}\text { Microcystis wesenbergii } \\
\text { [Pseudanabena mucicola; } \\
\text { Woronichinia compacta; } \\
\text { W. fusca; unidentified } \\
\text { picoplankton] }\end{array}$ & 6.2 & n.d. & 4.75 & 0.30 & 16 \\
\hline & WS18/08/2013 & $\begin{array}{l}\text { Microcystis botrys } \\
\text { M. cf. flos-aquae } \\
\text { M. wesenbergii }\end{array}$ & $\begin{array}{l}0.6 \\
7.2 \\
2.7\end{array}$ & $\begin{array}{c}\text { RR- } 0.1 \\
\text { YR- } 0.9 \\
\text { LR- } 0.2 \\
\mathrm{RR}+\mathrm{YR}+\mathrm{LR} / \mathrm{LR}= \\
1.2 / 0.2=6\end{array}$ & 4.20 & 0.16 & 26 \\
\hline & NS18/08/2013 & n.a. & n.a. & $\begin{array}{c}\text { RR- } 103.2 \\
\text { YR- } 47.6 \\
\mathrm{LR}-63.5 \\
\mathrm{RR}+\mathrm{YR}+\mathrm{LR} / \mathrm{LR}= \\
214.3 / 63.5=3.37\end{array}$ & - & - & - \\
\hline
\end{tabular}




\section{Continued}

\begin{tabular}{|c|c|c|c|c|c|c|c|}
\hline 6 & Vaya & $\begin{array}{l}\text { Lake for sport, fishing and } \\
\text { recreation }\end{array}$ & & & & & \\
\hline & $\begin{array}{c}\text { WS } \\
02 / 08 / 2012\end{array}$ & $\begin{array}{c}\text { Anabaena knipowitschii } \\
\text { Anabaena sp. } \\
\text { Aphanizomenon cf. yezoense } \\
\text { Dolichospermum compactum } \\
\text { Planktothrix agardhii } \\
\text { [cf. Aphanocapsa sp.; } \\
\text { Anabaenopsis elenkinii; } \\
\text { Aphanizomenon klebahnii] }\end{array}$ & $\begin{array}{l}15.1 \\
7.7 \\
3.5 \\
2.1 \\
2.5\end{array}$ & n.d. & 12.12 & 0.97 & 13 \\
\hline & WS16/08/2012 & $\begin{array}{c}\text { Aphanizomenon cf. yezoense } \\
\text { Aphanizomenon sp. st } \\
\text { Planktothrix agardhii } \\
\text { unidentified filamentous species } \\
\text { [cf. Planktothrix isothrix; } \\
\text { Planktolyngbya limnetica] }\end{array}$ & $\begin{array}{c}21.2 \\
11.1 \\
73.2 \\
1.5\end{array}$ & n.d. & 17.73 & 1.02 & 17 \\
\hline & WS21/08/2013 & $\begin{array}{c}\text { Anabaena sp. } \\
\text { Anabaenopsis elenkinii } \\
\text { Cylindrospermopsis raciborskii } \\
\text { Planktothrix agardhii }\end{array}$ & $\begin{array}{c}3.7 \\
5.9 \\
30.3 \\
164.7\end{array}$ & n.d. & 18.25 & 1.75 & 10 \\
\hline & NS21/08/2013 & n.a. & n.a. & n.d. & - & - & - \\
\hline
\end{tabular}

died water bodies are included with the following identification numbers: Momin Brod-IBW8307, StoudenaIBW1060, Pchelina-IBW 1039, Bistritsa-IBW 1067, Dourankoulak—IBW8825, and Vaya-IBW0191, in the Bulgarian Wetlands Inventory [14], where more details on them can be seen.

\subsection{Sampling}

Samples have been taken in summer and late summer-early autumn periods (July-October) of 2012-2014 (Table 1). For MC analyses quantitative samples of a liter and a half of water from surface layer $(0-20 \mathrm{~cm})$ were collected in plastic bottles and stored frozen prior to sample preparation. In parallel, qualitative samples were collected with plankton net (mesh size $20 \mu \mathrm{m}$ ) at the shallows with visible algal layers in the water column or scum on the water surface. These concentrated "biomasses" were stored frozen and portions of them were defrosted and dried at room temperature prior to the analysis of toxins. For the determination of total nitrogen and phosphorous other water samples of 1 liter were taken and the preservation was done with 2 to $4 \mathrm{ml}$ chloroform.

Water samples for microscopical analyses of the phytoplankton were collected in 1 liter glass bottles at the same points as the samples for toxins and immediately fixed with $10 \mathrm{ml}$ formaldehyde (35\% - 38\%). In the laboratory samples were concentrated to $30 \mathrm{ml}$ by standard sedimentation procedure ( $>48$ hours).

\subsection{Species Composition and Biomass Quantification of the Phytoplankton}

For microscopic analyses only quantitative water samples of $1.5 \mathrm{l}$ (sedimented to $30 \mathrm{ml}$ ) were processed. The qualitative analysis was based on taxa determination according to the current taxonomic literature [15]-[20]. Counts were done in a Thoma blood-counting chamber in 8 reiterations with cell as a counting unit [4]. Biomass was calculated after measurement of each cell, using standard stereometrical approximations [4] [21] [22]. The sedimented quantitative samples are kept in the Algological Collection of the Department of Botany, Faculty of Biology, Sofia University.

\subsection{Analysis of Nitrogen and Phosphorous}

Determination of these nutrients started in 2013-2014. The total nitrogen $(\mathrm{N})$ was performed using Kjeldahl method by "Kjeltec 2100", Foss Tecator technique. Analysis of total phosphorous (P) was done by spectrophoto- 
metric method at wavelength $700 \mathrm{~nm}$. The role of $\mathrm{N}$ and P biogenes as growth limiting factors was evaluated according to the total nitrogen/total phosphorus ratio (N/P) scale proposed by Forsberg et al. [23].

\subsection{Analysis of Toxins}

Stored water sample were frozen and defrosted three times to provide cell lysis. Afterwards samples were filtered through nylon membrane filter $0.45 \mu \mathrm{m}$ (Alltech). Extraction of MC and nodularin from water samples was performed by solid-phase extraction with Empore Extraction Disks C-18 (Varian). Toxins were eluted with methanol. Eluates were dried by gentle stream of nitrogen, re-dissolved in $500 \mu \mathrm{l}$ of $50 \%$ methanol (v/v), filtered through $0.22 \mu \mathrm{m}$ PTFE syringe filters (ALBET LabScience) and analyzed by HPLC.

Extraction of toxins from dried biomass was performed by ultrasonification of 40 to $60 \mathrm{mg}$ biomass in $1 \mathrm{ml}$ of $50 \%$ methanol $(\mathrm{v} / \mathrm{v})$. After centrifugation the methanolic extracts were filtered through $0.22 \mu \mathrm{m}$ PTFE syringe filters and analyzed by HPLC.

Analyses were performed by HPLC-DAD.

The HPLC-DAD system for quantitative and qualitative analyses includes Agilent 1200 Series coupled with Diode Array Detector (Agilent Technologies). Toxins were analyzed on a Supelcosil ABZ + Plus column (150 $\mathrm{mm} \times 4.6 \mathrm{~mm}, 5 \mu \mathrm{m}$, Supelco). The binary gradient of mobile phase consisted of milli-Q water $+0.1 \%$ TFA (A) and acetonitrile $+0.1 \%$ TFA (B) (linear increase from $20 \% \mathrm{~B}$ at $0 \mathrm{~min}$ to $46 \% \mathrm{~B}$ at $25 \mathrm{~min}$ and stop time 30 $\mathrm{min}$ ), the flow rate was $1 \mathrm{ml} / \mathrm{min}$, the temperature $25^{\circ} \mathrm{C}$. Chromatograms at $238 \mathrm{~nm}$ were recorded and toxins were identified by the retention time and characteristic UV absorption spectra from 200 to $300 \mathrm{~nm}$.

Purified MC-LR, -RR, -YR, and -LA (Abraxis) were used as external standards. The limit of determination for the quantitative water samples is $0.08-0.15 \mu \mathrm{g} / \mathrm{l}$ and for the net samples it is $5-10 \mu \mathrm{g} / \mathrm{g}$.

\section{Results and Discussion}

During the study, MC-LA and nodularin were not found, but presence of other MCs (-LR, -YR, -RR) was proved for all investigated water bodies (except Lake Vaya) in the period 2013-2014, while in 2012 MCs were detected in measurable amounts only in the samples from the lake Momin Brod. The cyanoprokaryotic taxa found and their biomass, the MC concentrations together with the amounts of total nitrogen and phosphorous and the $\mathrm{N} / \mathrm{P}$ ratio are shown in Table 1.

The occurrence of MCs in the examined water bodies was irregular in terms of time (Table 1). When found, the concentrations of intra + extracellular MCs in water samples ranged from 0.37 to $1.8 \mu \mathrm{g} / \mathrm{l}$, while the amount of total MCs in the net samples ranged from 10.9 to $296.1 \mu \mathrm{g} / \mathrm{g}$ (d.w.) (Table 1).

In the samples from the lake Vaya, collected in 2012 and 2013, MCs were not detected. The same was the situation in 2011 and 2005 and only earlier, in 2004 -RR, -YR and -LR were found there [10]-[13]. The lack of MCs is explainable by the species composition in the lake at the time of sampling in this (Table 1 ) and previous [24]-[28] studies. However, in all samples some potential producers of other cyanotoxins were recorded. For example, the neurotoxin anatoxin-a (ANA) "has been detected in natural populations of cyanobacteria when Anabaena, Oscillatoria, Aphanizomenon, Cylindrospermum, Planktothrix, and Raphidiopsis dominate the cyanobacterial community" [29]. ANA-producing strains have been isolated from all of these genera [30] [31] and representatives of all them (incl. Dolichospermum as recently splitted from Anabaena [17] [20]) have been found in significant amounts in the lake waters in different periods (Table 1, [14] [24]-[28]). Concerning biomass, Planktothrix agardhii is one if the "key players" in the phytoplankton of Lake Vaya [14] [25]-[28]. For this species toxicity and presence of high amounts of MCs was indicated [e.g. [32] and in addition toxic effects independent of MC content were proved [33]. From the potentially toxic (and frequently reported as toxic [32], capable also of cylindorspermopsin production [34] [35]) species Aphanizomenon flos-aquaethe variety klebahnii was separated. The last seems to be more widespread than the typical variety and most recently it was recognized as a separate species [17] [20]. A. klebahnii was also found in the phytoplankton of Vaya Lake, and in spite that it is more often regarded as non-toxic [32] its presence still has to be considered with carefulness when harmful blooms are discussed. The high values of Cylindrospermopsis raciborskii biomass, detected in 2013 (Table 1), confirm the relatively stable "lodging" there of this exotic species, found in big amounts in the lake since 2000 [25]-[28]. C. Raciborskii is well known for producing toxins, including cylindrospermopsin (hepatotoxin; CYN) and saxitoxin (neurotoxin), although non toxin-producing strains are also observed (e.g. [31] [35][38]). In addition to the dominant toxin, the toxic alkalloid CYN, recently a deoxy-cylindrospermopsin was is- 
olated from Japanese strain ISG9 of this species [39] and some other toxic metabolities were found in a strain from a temperate zone, unable to synthesize CYN [40]. This first study on the cell-free extracts of a non-CYNproducing strain of $C$. raciborskii in human cells (neutrophils and lymphocytes) showed that the observed effects were compared to those induced by CYN $\left(1.0-0.01 \mu \mathrm{g} \cdot \mathrm{mL}^{-1}\right)$ and also some other effects (e.g. increased necrosis and apoptosis in neutrophils and elevated apoptosis in lymphocytes), not induced by CYN, regardless of the toxin concentration, were registered. From these results was concluded that strains occurring in temperate zones may pose a threat to human health through the production of hitherto unknown metabolites that reveal a toxic pattern different to that of CYN [40]. This discovery again shows the possibility of C. raciborskii to cause water-safety problems and emphasizes the need for basic monitoring schemes for this species in water supplies, especially in those located in the temperate regions. Therefore, in spite of the recent negative results, the high MC concentration in 2004 [11]-[13] together with the presence of potential producers of other cyanotoxins and toxic metabolites on the background of the strong blue-green algal blooms, observed since years in the lake ([14] [24]-[28] Table 1) suggest the necessity of permanent monitoring of Vaya and prove its inclusion in the Red List of Bulgarian wetlands in Critically Endangered category [41] [42].

During this study, MCs were not detected also in the reservoir Bistritsa, with one exception of the sample examined from water remains after the draining of the reservoir in 2013 (Table 1). The same was the situation in 2011 and in 2005, when MCs were not found. Only once, in 2004, extracellular MCs were identified in reservoir waters [10] [12] [13]. In all samples, which show positive results for MC presence in this and previous studies, the microscopic work revealed presence of Microcystis species (Table 1, [10]). The lack of MCs in most of the samples is easily explainable with the phytoplankton species composition, in which different, but non-toxic representatives from almost all algal groups have been determined (e.g. from genera Ceratium, Euglena, Pediastrum, Phacotus, Phacus, Polyedriopsis, Tetraedron, Trachelomonas, among the many others)

Results from the sample analyses for the mountain drinking water reservoir Stoudena show general lack of MCs, with the exception of both quantitative water and net samples from October 2013 (Table 1). The same was the situation with our previous studies of this reservoir, when only once, in 2011, 0.1 $\mu \mathrm{g} / \mathrm{l} \mathrm{MYC-LR}$ was found [10], while in all samples from 2004 and 2005 no MC was detected [11]-[13]. The amount of MC in net samples from the same date of October 2013, as it could be expected, is much higher (10.9 $\mu \mathrm{g} / \mathrm{g}$ in total, and $8.11 \mu \mathrm{g} / \mathrm{g}$ of LR) than in water samples (only $01 \mu \mathrm{g} / \mathrm{l}$ MYC-LR) (Table 1). During this study, for first time -YR and -RR were found in the examined samples. This, together with the confirmation of the presence of MYC-LR - one of the most toxic cyanotoxins - in this drinking water reservoir, confirms our previous opinion and proposal [10] for stronger permanent control of its water quality and necessity of taking measures with appropriate steps for its improvement in the nearest future. In spite of the fact that the concentration of the toxin is 10 times lower than WHO limit of $1 \mu \mathrm{g} / \mathrm{l}$, the data obtained on both higher MC presence and more abundant development of cyanoprokaryotic taxa (which were not typical for this water body [14]) are a strong alert about on-going negative processes in this reservoir. They are probably due to a combination of factors leading to a general worsening of the sanitary protection of the water basin (contamination with nitrogen and phosphorous, data about which at present are unavailable [10]) on the background of global warming, which seems to enhance the development of cyanoprokaryotes.

During this study MCs were found in Dourankoulak Lake only in the samples from 2013 (Table 1). Their concentrations are much lower in water samples when comparison with our previous results on MCs from 2004, 2005 and 2011, obtained by HPLC and DAD is made [10]-[13]. The algological studies show permanent presence of potentially toxic cyanobacteria in this coastal wetland during the last 22 years [11] [25] [28] [43] [44]. Nevertheless that in this studythe concentration of MYC-LR in the water sample is lower than maximal permissible level $20 \mu \mathrm{g} / \mathrm{l}$ for bathing water according to [45] in the country (as was the situation in 2011 [10]), we confirm our previous opinion that this lake, undergoing strong eutrophication process, should be object of special monitoring, restoration measures and conservation activities [10] [11] [43] [44], as well as its inclusion in the Red List of Bulgarian wetlands in Critically Endangered category [41] [42]. The contradictory opinions on the toxicity/non-toxicity of one of the most often found and important species in the phytoplankton of Dourankoulak-Microcystis wesenbergii-were discussed in our previous paper [10]. Here we would like to add that in 2012 it was indicated again as a "definitely toxigenic species" [46] and included in the "list of species that have been confirmed to have toxin-producing strains" [47]. Two more Microcystis species-Microcystis flos-aquae and $M$. viridis - were identified in MC-containing samples from the lake (Table 1). The both species were noted among the potentially toxic producers ([32] and citations there). However, in comparison with M. viridis, for 
which toxicity and especially MC presence were often indicated (e.g. [6] [48]-[52] and citations therein), according to our knowledge, $M$. flos-aquae was much more rarely definitelypointed as a toxigenic species. For example,its toxic and lethal effects on animals were noted [53] [54] and later a study of its strain from a Spanish-drinking water reservoir Santillana proved that it contained 4 major MCs: MC-LR, MC-LF, MC-LW, and MC-LY [55].

Positive results were obtained from one sampling also in the reservoir Pchelina, where in October 2014 three MCs (-YR, -RR and -LR) in both quantitative water and net samples were found (Table 1). The microscopic investigation revealed only presence of big amount of separate, identical ellipsoidal cyanoprokaryotic resting cells-akinetes, the identification of which is impossible on species level. Their occurrence clearly shows that left behind was a development of heterocystous filamentous algae. Such types of akinetes are known for example in genera Anabaena L., Anabaenopsis, Aphanizomenon, etc. [17] [18], some species of which are capable of cyanotoxin production [6] [7]. In the samples from 2011, when only MC-RR was detected, Aphanizomenon sp. was found in the summer-late summer samples of the same reservoir [10]. By contrast, in 2012, when a bloom of Anabaena sp. st. was found, no MCs were detected in water and net samples (Table 1). In our previous studies of the same reservoir in 2004 all three MCs were found in the "biomass" from net samples (LR + RR + YR/LR = 536/140), but dissolved MC were not found in water samples [12]. The confirmation of MC presence and their high concentration in net samples are relevant to our previous statement that in certain conditions this reservoir may be hazardous for a recreational use [10].

The results of N/P ratio analysis show its high value (ranging between 17 and 218-Table 1) and indicate the P limitation of all studied water bodies according to [23]. However, due to low amount of samples investigated, no significant correlation was found between MC presence, quantities and amounts of these biogenes.

The detected maximum concentrations of MCs from Bulgarian water bodies are lower in quantitative water samples, but higher in net samples, when a comparison with our previous study [10] is made. As discussed there, they are still close to the quantities reported from other European countries (e.g. [55]-[62]) and are still lower in comparison with the amounts found in the Czech Republic — up to $36 \mu \mathrm{g} / \mathrm{l}$ dissolved MCs in water bodies [63] and Slovakia —up to $1445.5 \mu \mathrm{g} / \mathrm{g}$ d.w. in "biomasses" [64]. The values obtained by us during this and previous studies [10]-[13] are generally higher in comparison with other investigations, revealing MCs in Bulgaria (e.g. [65]-[67]). This result is explainable mostly with the differences in the geographic location, morphometric features and detected biodiversity in the examined water bodies [14].

\section{Conclusion}

The results from this study, obtained during the period 2012-2014, show the presence of cyanotoxins MCs in five of the six investigated water bodies. When found, they ranged from 0.1 to $1.8 \mu \mathrm{g} / \mathrm{l}$ in quantitative water samples and from 1.35 to $296 \mu \mathrm{g} / \mathrm{g} \mathrm{d}$.w. in concentrated biomasses from net samples. Despite the fact that in 2012 MCs were not found in five of the all six studied water bodies and that the registered MCs were still lower in comparison with some other European countries, the presence of samples in which the most toxic MC-LR was recorded could serve as a strong alarm for the necessity of a serious study and relevant discussion of the problem with responsible authorities at national level with need of recognition of the problem as a new health risk factor. This statement conforms to our previous conclusions [10] and finds additional support in the recorded high biomass of cyanoprokaryotes, which indicates presence of their blooms in the studied wetlands. Considering that a lack of correlation between the toxicity and the MC content in cyanobacterial samples has also been observed [33] [68], the presence of such blooms of potentially toxic species can serve as indication of potential risk and water-safety problems. Therefore, permanent monitoring with identification of toxins in water bodies at risk and activities for limitation and control of toxic blooms are urgently needed, in combination with increase of the attention to the effects of cyanotoxins on both human health and health of aquatic ecosystems in Bulgaria.

\section{Acknowledgements}

Authors are thankful for the financial support of MESY scientific projects DDVU-02/77 and DFNI-T01/5 NANOSORBLAB. One of the authors of this paper, B. Uzunov, participates in the Project № BG051PO0013.3.06-0045/18.07.2013 in Human Resources Development Operational Programme, to which thankfulness is due. The authors would like to acknowledge the European Cooperation in Science and Technology, COST Action ES 1105 "CYANOCOST-Cyanobacterial blooms and toxins in water resources: Occurrence, impacts and 
management" for adding value to this study through networking and knowledge sharing with European experts and researchers in the field.

\section{References}

[1] Schopf, J.W. and Walter, M.R. (1982) Origin and Early Evolution of Cyanobacteria: The Geological Evidence. In: Carr, C.C. and Whitton, B.A., Eds., The Biology of Cyanobacteria. Botanical Monographs, Blackwell Scientific Publications, Oxford, Vol. 19, 543-564.

[2] Lee, R.E. (2008) Phycology. 4th Edition, Cambridge University Press, Cambridge, 531.

[3] Graham, L.E., Graham, J.M. and Wilcox, L.W. (2009) Algae. Benjamin Cummings, San Francisco, 720.

[4] Temniskova, D. and Stoyneva, M. (2011) Algology. General Part. Vol. 1, Pensoft, Sofia-Moscow, 1-512. (In Bulgarian)

[5] Temniskova, D. and Stoyneva, M. (2011) Algology. Systematic Part. Vol. 2, Pensoft, Sofia-Moscow, 513-1040. (In Bulgarian)

[6] Chorus, I. and Bartram, J., Eds. (1999) Toxic Cyanobacteria in Water: A Guide to Public Health Significance, Monitoring and Management. E\&FN Spon, London. http://dx.doi.org/10.4324/9780203478073

[7] Huisman, J., Matthijs, H.C.P. and Visser, P.M., Eds. (2005) Harmful Cyanobacteria. Springer, Berlin, 241. http://dx.doi.org/10.1007/1-4020-3022-3

[8] United States Environmental Protection Agency, Office of Water 4304T2012. Cyanobacteria and Cyanotoxins: Information for Drinking Water Systems. EPA-810F11001 July. http://water.epa.gov/scitech/swguidance/standards/criteria/nutrients/upload/cyanobacteria_factsheet.pdf

[9] WHO (1998) Guidelines for Drinking-Water Quality, Health Criteria and Other Supporting Information. 2nd Edition, Addendum to Vol. 2, World Health Organization, Geneva, 253.

[10] Pavlova, V., Stoyneva, M., Georgieva, V., Donchev, D., Spoof, L., Meriluoto, J., Bratanova, Z. and Karadjova, I. (2014) New Records of Microcystins in Some Bulgarian Water Bodies of Health and Conservational Importance. Journal of Water Resource and Protection, 6, 446-453. http://dx.doi.org/10.4236/jwarp.2014.65044

[11] Pavlova, V., Stoyneva, M., Babica, P., Kohoutek, J. and Bratanova, Z. (2007) Microcystins Contamination and Cyanoprokaryote Blooms in Some Coastal Bulgarian Wetlands. Conference Preprint Book, BULAQUA 2007, Second International Conference and Exhibition of Water Resources, Technologies and Services, Sofia, 6-7 June 2007, 221-226.

[12] Pavlova, V., Babica, P., Todorova, D., Bratanova, Z. and Maršálek, B. (2006) Contamination of Some Reservoirs and Lakes in Republic of Bulgaria by Microcystins. Acta Hydrochim Hydrobiol, 34, 437-441. http://dx.doi.org/10.1002/aheh.200600641

[13] Pavlova, V. (2007) Hygiene and Analytical Aspects of Microcystins Occurrence in Surface Water. Ph.D. Dissertation, National Center of Public Health Protection, Sofia.

[14] Michev, T.M. and Stoyneva, M.P., Eds. (2007) Inventory of Bulgarian Wetlands and Their Biodiversity. Part 1: NonLoticWetlands. Publishing House Elsi-M, Sofia, 364.

[15] Komárek, J. and Anagnostidis, K. (1999) Cyanoprokaryota. 1. Teil: Chroococcales. In: Ettl, H., Gärtner, G., Heynig, G. and Mollenhauer, D., Eds., Süßwasserflora von Mitteleuropa, Bd. 19 (1), Gustav Fischer, Jena, 1-548.

[16] Komárek, J. and Anagnostidis, K. (2005) Cyanoprokaryota. 2. Teil: Oscillatoriales. In: Büdel, B., Gärtner, G., Krienitz,L. and Schagerl, M., Eds., Süßwasserflora von Mitteleuropa, Bd. 19 (2), Elsevier GmbH, München, 1-759.

[17] Komárek, J. (2013) Cyanoprokaryota: 3rd Part: Heterocystous Genera. In: Büdel, B., Gärtner, G., Krienitz, L. and Schagerl, M., Eds., Süßwasserflora von Mitteleuropa, Bd. 19 (3), Springer Spektrum, Berlin, Heidelberg, 1-1130.

[18] Komárek, J., Kaštovskšý, J., Mareš, J. and Johnsen, J. (2014) Taxonomic Classification of Cyanoprokaryotes (Cyanobacterial Genera) 2014, Using a Polyphasic Approach. Preslia, 86, 295-335.

[19] Hindák, F. (2008) Colour Atlas of Cyanophytes. VEDA, Bratislava, 251.

[20] Guiry, M.D. and Guiry, G.M. (2015) AlgaeBase. World-Wide Electronic Publication. National University of Ireland, Galway. http://www.algaebase.org

[21] Rott, E. (1981) Some Results from Phytoplankton Counting Intercalibration. Schweizerische Zeitschrift für Hydrologie, 43, 34-62. http://dx.doi.org/10.1007/bf02502471

[22] Deisinger, G. (1984) Leitfaden zur Bestimmung der planktischen Algen der Kärntner Seen und ihrer Biomasse. Zusammengestellt von Kärntner Institut fur Seenforschung.

[23] Forsberg, C., Ryding, S.-O., Claesson, A. and Forsberg, A. (1978) Water Chemical Analyses and/or Algal Assay? Sewage Efficient and Polluted Water Studies. Mitteilungen Internationale Vereinigung für Theoretische und Angewandte Limnologie, 21, 352-363. 
[24] Stoyneva, M.P. (2003) Steady-State Phytoplankton Assemblages in Shallow Bulgarian Wetlands. In: Naselli-Flores, L., Padisak, J. and Dokulil, M., Eds., Phytoplankton and Equilibrium Concept: The Ecology of Steady-State Assemblages. Kluwer Academic Publishers, Dordrecht, 169-176. http://dx.doi.org/10.1007/978-94-017-2666-5_15

[25] Stoyneva, M.P. (2014) Contribution to the Studies of the Biodiversity of Hydro- and Aerobiontic Prokaryotic and Eukaryotic Algae in Bulgaria. Dr. Sc. Dissertation, Sofia University “St. Kliment Ohridski”, Sofia.

[26] Dimitrova, R.E., Nenova, E.P., Uzunov, B.A., Shihiniova, M.D. and Stoyneva, M.P. (2014) Phytoplankton Composition of Vaya Lake (2004-2006). Bulgarian Journal of Agricultural Sciences, 20, 165-172.

[27] Dimitrova, R.E., Nenova, E.P., Uzunov, B.A., Shihiniova, M.D. and Stoyneva, M.P. (2014) Phytoplankton Abundance and Structural Parameters of the Critically Endangered Protected Area Vaya Lake (Bulgaria). Biotechnology \& Biotechnological Equipment, 28, 871-877. http://dx.doi.org/10.1080/13102818.2014.947718

[28] Stoyneva, M.P. (2015) Allochtonous Planctonic Algae Recorded in Bulgaria during the Last 25 Years and Their Possible Dispersal Agents. Phytoplankton \& Spatial Gradients, Published Online. http://dx.doi.org/10.1007/s10750-015-2334-x

[29] Carrasco, D., Moreno, E., Paniagua, T., de Hoyos, C., Wormer, L., Sanchis, D., Cirés, S., Martín-del-Pozo, D., Codd, G.A. and Quesada, A. (2007) Anatoxin-A Occurrence and Potential Cyanobacterial Anatoxin-A Producers in Spanish Reservoirs. Journal of Phycology, 43, 1120-1125. http://dx.doi.org/10.1111/j.1529-8817.2007.00402.x

[30] Codd, G.A., Morrison, L.F. and Metcalf, J.S. (2005) Cyanobacterial Toxins: Risk Management for Health Protection. Toxicology and Applied Pharmacology, 203, 264-272. http://dx.doi.org/10.1016/j.taap.2004.02.016

[31] Botana, L.M. and Alfonso, A., Eds. (2015) Phycotoxins: Chemistry and Biochemistry. 2nd Edition, Wiley Blackwell, John Wiley \& Sons Ltd., Hoboken, 544. http://dx.doi.org/10.1002/9781118500354

[32] Chorus, I, Ed. (2012) Cyanotoxins: Occurrence, Causes, Consequences. Springer Science \& Business Media, Berlin, 357. http://dx.doi.org/10.1007/978-3-642-29151-7_4

[33] Palíkova, M., Krejc, R., Hilscherová, K., Babica, P., Navrátil, S., Kopp, R. and Bláha, L. (2007) Effect of Different Cyanobacterial Biomasses and Their Fractions with Variable Microcystin Content on Embryonal Development of Carp (Cyprinus carpio L.). Aquatic Toxicology, 81, 312-318. http://dx.doi.org/10.1016/j.aquatox.2007.01.001

[34] Preussel, K., Stuken, A., Wiedner, C., Chorus, I. and Fastner, J. (2006) First Report on Cylindrospermopsin Producing Aphanizomenonflos-aquae (Cyanobacteria) Isolated from two German Lakes. Toxicon, 47, 156-162. http://dx.doi.org/10.1016/j.toxicon.2005.10.013

[35] Botana, L.M., Louzao, C. and Vilariño, N., Eds. (2015) Climate Change and Marine and Freshwater Toxins. Walter de Gruyter GmbH \& Co KG, Berlin, 520. http://dx.doi.org/10.1515/9783110333596

[36] Stucken Marin, K.S. (2010) Physiogenomics of Cylindrospermopsis raciborskii and Raphidiopsis brookii (Cyanobacteria) with Emphasis on Evolution, Nitrogen Control and Toxin Biosynthesis. Ph.D. Thesis, Faculty of Biology and Chemistry (Fachbereich 2), University of Bremen, Bremen.

[37] Stucken, K., Murillo A.A., Soto-Liebe K., Fuentes-Valdés J.J., Méndez M.A. and Vásquez, M. (2009) Toxicity Phenotype Does Not Correlate with Phylogeny of Cylindrospermopsis raciborskii Strains. Systematic and Applied Microbiology, 32, 37-48. http://dx.doi.org/10.1016/j.syapm.2008.10.002

[38] Alster, A., Kaplan-Levy, R.N., Sukenik, A. and Zohary, T. (2010) Morphology and Phylogeny of a Non-Toxic Invasive Cylindrospermopsis raciborskii from a Mediterranean Lake. Hydrobiologia, 639, 115-128. http://dx.doi.org/10.1007/s10750-009-0044-y

[39] Zarenezhad, S., Sano, T., Watanabe, M.M. and Kawachi, M. (2012) Evidence of the existence of a toxic form of Cylindrospermopsis raciborskii (Nostocales, Cyanobacteria) in Japan. Phycological Research, 60, 98-104. http://dx.doi.org/10.1111/j.1440-1835.2012.00639.x

[40] Poniedziałek, B., Rzymski, P., Kokociński, M. and Karczewski, J. (2015) Toxic Potencies of Metabolite(s) of NonCylindrospermopsin Producing Cylindrospermopsis raciborskii Isolated from Temperate Zone in Human White Cells. Chemosphere, 120, 608-614. http://dx.doi.org/10.1016/j.chemosphere.2014.09.067

[41] Michev, T.M. and Stoyneva, M.P. (2005) Red List of Bulgarian Wetlands: Conception, Creation and Application. Annuaire de l’Université de Sofia “St. Kliment Ohridski”, Livre 4-10ème Session Scientifigue, Sofia’03, Partie II, Tome 96, 71-76.

[42] Michev, T.M. and Stoyneva, M.P. (2007) Conservation of Bulgarian Non-Lotic Wetlands. In: Michev, T.M. and Stoyneva, M.P., Eds., Inventory of Bulgarian Wetlands and Their Biodiversity, Part 1: Non-Lotic Wetlands, Publishing House Elsi-M, Sofia, 109-131.

[43] Stoyneva, M.P. (2000) Algological Studies of Bulgarian Coastal Wetlands. I. Species Composition of the Phytoplankton of Durankulak and Shabla-Ezeretz Lakes. Annual of Sofia University, 91, 27-48.

[44] Stoyneva, M.P. (2002) Algological Studies of Bulgarian Coastal Wetlands. II. Quantitative Structure of the Phytoplankton of Durankulak and Shabla-Ezeretz Lakes. Annual of Sofia University, 92, 91-109. 
[45] WHO (2003) Guidelines for Safe Recreational Water Environments. Vol. 1. Coastal and Fresh Water. Chapter 8. Algae and Cyanobacteria in Fresh water. World Health Organization, Geneva, 151.

[46] Carmicahel, W.W. and Falconer, J.R. (1993) Chapter 12: Diseases Related to Freshwater Blue-Green Algal Toxins, and Control Measures. In: Falconer, J.R., Ed., Algal Toxins in Seafood and Drinking Water, The University Press, Cambridge, 187-210. http://dx.doi.org/10.1016/B978-0-08-091811-2.50017-4

[47] Skulberg, O.M., Carmichael, W.W., Codd, J., Falconer, J.R. and Skulberg, R. (1993) Chapter 9: Taxonomy of Toxic Cyanophyceae (Cyanobacteria). In: Falconer, J.R., Ed., Algal Toxins in Seafood and Drinking Water, The University Press, Cambridge, 145-164. http://dx.doi.org/10.1016/B978-0-08-091811-2.50014-9

[48] Falconer, J.R. (2005) Cyanobacterial Toxins of Drinking Water Supplies. Cylindrospermopsins and Microcystins. CRC Press, Boca Raton, 304.

[49] Botana, L.M., Ed. (2008) Seafood and Freshwater Toxins: Pharmacology, Physiology, and Detection. 2nd Edition, CRC Press, Taylor and Francis Group, Boca Raton, 552.

[50] Ooi, T., Kusumi, T., Kakisawa, H. and Watanabe, M.M. (1989) Structure of Cyanoviridin RR, a Toxin from the BlueGreen Alga. Microcystis viridis. Journal of Applied Phycology, 1, 31-38. http://dx.doi.org/10.1007/BF00003533

[51] Song, L., Sano, T., Li, R., Watanabe, M.M., Liu, Y. and Kaya, K. (1998) Microcystin Production of Microcystis viridis (Cyanobacteria) under Different Culture Conditions. Phycological Research, 46, 19-24.

[52] Watanabe, M.F., Oishi, S., Watanabe, Y. and Watanabe, M. (1986) Strong Probability of Lethal Toxicity in the BlueGreen Alga Microcystis viridis Lemmermann. Journal of Phycology, 22, 552-556. http://dx.doi.org/10.1111/j.1529-8817.1986.tb02502.x

[53] Fitch, C.P., Bischop, L.M., Lucille, M., Boyd, W.L., Gortner, R.A., Rogers, C.F. and Tilden, J.E. (1934) Water Bloomas a Cause of Poisoning in Domestic Animals. Cornell Veterinarian, 24, 30-39.

[54] Tripathy, A.K. and Pandey, S.N. (2009) Water Pollution. Ashish Publishing House, New Delhi, 326.

[55] Padilla, C., Sanz-Alférez, S. and del Campo, F.F. (2006) Toxin Characterisation and Identification of a Microcystis flos-aquae Strain from a Spanish Drinking-Water Reservoir. Archiv Fur Hydrobiologie, 165, 383-399. http://dx.doi.org/10.1127/0003-9136/2006/0165-0383

[56] Albay, M., Matthiensen, A. and Codd, G. (2005) Occurrence of Toxic Blue-Green Algae in the Kucukcekmece Lagoon (Istanbul, Turkey). Environmental Toxicology, 20, 277-284. http://dx.doi.org/10.1002/tox.20118

[57] Funari, E., Gramaccioni, L. and Scardala, S. (2005) Cyanobacteria in Surface Water. In: Chorus, I., Ed., Current Approachesto Cyanotoxin Risk Assessment, Risk Management and Regulations in Different Countries, WaBoLu-Hefte, Federal Environmental Agency (Umweltbundesamt), Berlin, 81-83.

[58] Mankiewicz, J., Jurczak, T., Izydorczyk, K. and Zalewski, M. (2005) Regulation on Cyanotoxins in Legislation. In: Chorus, I., Ed., Current Approaches to Cyanotoxin Risk Assessment, Risk Management and Regulations in Different Countries, Wa BoLu-Hefte. Federal Environmental Agency (Umweltbundesamt), Berlin, 99-101.

[59] Pantelić, D., Svirčev, Z., Simeonović, J., Vidović, V. and Trajković, I. (2013) Cyanotoxins: Characteristics, Production and Degradation Routes in Drinking Water Treatment with Reference to the Situation in Serbia. Chemosphere, 1, 421441. http://dx.doi.org/10.1016/j.chemosphere.2013.01.003

[60] Blinkova, M., Zdraveski, N. and Krastić, S.S. (2012) Blue-Green Algae, the Janus of Nature. Proceedings of the 5th International Scientific Conference BALWOIS 2012, Ohrid, 28 May-2 June 2012, 1-12.

[61] Cook, C.M., Moustaka-Gouni, M., Gkelis, S. and Lanaras, T. (2005) Cyanotoxin Risk Assessment, Risk Management and Regulation. In: Chorus, I., Ed., Current Approaches to Cyanotoxin Risk Assessment, Risk Management and Regulationsin Different Countries, WaBoLu-Hefte, Federal Environmental Agency (Umweltbundesamt), Berlin, 6975.

[62] Boaru, D.A., Dragoş, N., Welker, M., Bauer, A., Nicoară, A. and Schirmer, K. (2006) Toxic Potential of MicrocystinContaining Cyanobacterial Extracts from Three Romanian Freshwaters. Toxicon, 47, 925-932. http://dx.doi.org/10.1016/j.toxicon.2006.02.015

[63] Juković, M., Svirčev, Z., Baltić, V., Stojanović, D., Mihajlovic, A. and Baltić, M. (2008) Cyanotoxins-New Health Risk Factor in Serbia. Archive of Oncology, 16, 55-58. http://dx.doi.org/10.2298/AOO0804055J

[64] Bláhova, L., Babica, P., Adamovsky, O., Kohoutek, J., Maršalek, B. and Bláha, L. (2008) Analyses of Cyanobacterial Toxins (Microcystins, Cylindrospermopsin) in the Reservoirs of the Czech Republic and Evaluation of Health Risks. Environmental Chemistry Letters, 6, 223-227. http://dx.doi.org/10.1007/s10311-007-0126-x

[65] Maršálek, B., Bláha, L. and Hindák, F. (2000) Review of Toxicity of Cyanobacteria in Slovakia. Biologia, 55, 645-652.

[66] Teneva, I., Mladenov, R., Belkinova, D., Dimitrova-Dylgerova, I. and Dzhambazov, B. (2010) Phytoplankton Community of the Drinking Water Supply Reservoir Borovitsa (South Bulgaria) with an Emphasis on Cyanotoxins and Water Quality. Central European Journal of Biology, 5, 231-239. 
[67] Teneva, I., Belkinova, D., Dimitrova-Dylgerova, I. and Mladenov, R. (2009) Phytoplankton Assemblages and Monitoring of Cyanotoxins in Trakiets Reservoir. Scientific Researches of the Union of Scientists in Bulgaria-Plovdiv, Series B, Natural Sciences and the Humanities, 12, Technics, Technologies, Natural Sciences and Humanities Session.

[68] Teneva, I., Belkinova, D., Dimitrova-Dylgerova, I., Vlaknova, M. and Mladenov, R. (2010) Comparison and Toxic Potentialof Cyanoprokaryota in Vacha Dam (Bulgaria). Second Balkan Conference on Biology, Plovdiv, 21-23 May 2010, 26-32.

[69] Palíkova, M., Navrátil, S., Maršálek, B. and Bláha, L. (2003) Toxicity of Crude Extract of Cyanobacteria for Embryos and Larvae of Carp (Cyprinus carpio L.). Acta Veterinaria Brno, 72, 437-443.

http://dx.doi.org/10.2754/avb200372030437 